RESEARCH ARTICLE

\title{
The Development of the French Version of the Psychological Sense of School Membership (PSSM) Questionnaire: An Analysis of its Structure, Properties and Potential for Research with at-risk Students
}

\author{
Jerome St-Amand ${ }^{1 *}$, Robert Boily ${ }^{2}$, Francois Bowen ${ }^{2}$, Jonathan Smith ${ }^{3}$, Michel \\ Janosz $^{2}$, and Jérémie Verner-Filion ${ }^{1}$
}

${ }^{1}$ Université du Québec en Outaouais, Canada

2Université de Montréal, Canada

${ }^{3}$ Université de Sherbrooke, Canada

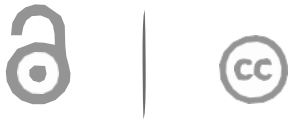

Open Access

Citation: St-Amand, J, Boily R, Bowen F, Smith J, Janosz M, Verner-Filion J. The Development of the French Version of the Psychological Sense of School Membership (PSSM) Questionnaire: An Analysis of its Structure, Properties and Potential for Research with at- risk Students. Interdisciplinary Education and Psychology. 2020; 2(3):3.

Received: December 19, 2019 Accepted: May 21, 2020

Published: June 05, 2020

Copyright: @2020 St-Amand, J. This is an open access article distributed under the terms of the Creative Commons Attribution License, which permits unrestricted use, distribution, and reproduction in any medium, provided the original author and source are credited.

\section{Corresponding author:}

Jerome St-Amand, Université du Québec en Outaouais, Canada. E-mail: jerome.st-amand@uqo.ca

\begin{abstract}
Introduction. As it plays an important role in students' adjustment, and positively impacts their motivation and academic success, school belonging seems to be a pivotal determinant of the overall quality of a school experience. However, measuring such a belonging and estimating its contribution to the overall quality of school adjustment remain a challenge for the scientific community.

Method. Thus, the French version of the Psychological Sense of School Membership (PSSM) questionnaire was tested to determine its latent structure, validity, and capacity to predict dropout among at-risk students. In Study 1, the French version of the PSSM scale was thoroughly analyzed for validity while performing exploratory factor analysis, confirmatory factor analysis, and multigroup confirmatory factor analysis on selfreported data provided by a sample of high school students. In study 2, answers of a particular sample of at-risk students were carefully analyzed with ANOVAS to determine the potential of the PSSM to predict high school dropout.

Results. The exploratory factor analysis and the confirmatory factor analysis revealed four predominant dimensions: (1) teacher-student relationships; (2) peers' relationships; (3) sense of acceptance; and (4) sense of attachment, while the multigroup confirmatory factor analysis revealed the PSSM to be partially invariant with regards to the gender of the participants. In Study 2, we found that the PSSM can be used as a tool to help identify students who are at risk of dropping out of school.
\end{abstract}

Conclusion. Strategies to develop students' school belonging are discussed.

\section{Background}

Individuals have unique ambitions and goals; they feel an innate need to connect with others (Baumeister \& Leary, 1995; Lavigne, Vallerand, \& Crevier-Braud, 2011); they seek to love and to be loved, to look after others, and to be looked after (Deci \& Ryan, 2000). The will to develop strong bonds with others is in fact universal (Baumeister \& Leary, 1995; St-Amand, Bowen, \& Lin, 2017).

In school environments, it has been observed that school belonging positively impacts a number of dispositions, for example, expectancy of success, value of schoolwork, and selfreported effort (Goodenow \& Grady, 1993b), as well as school engagement and achievement (Allen, Kern, Vella- Brodick, Hattie, \& Waters, 2016; Eccles \& Roeser, 2009; Gillen-O'Neel \& Fuligni, 2013; Juvonen, 2006; Roeser, Midgley, \& Urdan, 1996; Wehlage, Rutter, Smith, Lesko, \& Fernandez, 1989). Different specialists have noticed a positive and significant relationship 
between school belonging and interest in extracurricular activities, school attendance rates (Flynn, 1997), quality social relations (Hagborg, 1994), and positive psychological well- being (Hagerty, Williams, Coyne, \& Early, 1996). In her literature review, Osterman (2000) pointed out the importance of this concept for students' motivation, engagement and persistence.

On the other hand, a low level of student's school belonging is a dropout factor that ought to be genuinely considered (Berktold, Geis, \& Kaufman, 1998; Vera, Polanin, Polanin, \& Carr, 2018). Since the mid 1970's, in fact, school belonging has been closely linked to school dropout at high school (Beaumeister \& Leary, 1995; Finn, 1989; St-Amand, 2016; Wehlage, 1989) and even at university levels (Tinto, 1975). As Berktold, Geis and Kaufman (1998) noted in their study: "The dropouts at greatest risk of not completing high school left school at a very young age [...] and did not connect with institutional sources of support" (p. 15). Christenson and Thurlow (2004, p. 37) corroborated these observations by noting that a low level of membership is an important indicator marking the disengagement processes of students at school:

"[...] dropout is preceded by indicators of withdrawal (e.g., poor attendance) or unsuccessful school experiences (e.g., academic or behavioral difficulties) that often begin in elementary school. Overt indicators of disengagement are generally accompanied by feelings of alienation, a poor sense of belonging, and a general dislike for school".

\section{Toward an understanding of school belonging}

Goodenow (1993a) defines belonging as a sense of being accepted, valued, included, and encouraged by others (e.g., teachers, peers, etc.) in the classroom. This feeling also implies support and respect for personal autonomy, such as the fact that students can be part of school life, including participating in activities. Juvonen (2006) conceptualizes this feeling as a need that leads to behavior change or as a result of the characteristics of the social context. In the same line of thoughts, the need to interact with others is indeed innate and universal, just like the need to establish stable and loving relationships (Beaumeister \& Leary, 1995; StAmand, 2016). The works of Baumeister and Leary (1995) suggest that belonging is a fundamental human motivation because it meets several important criteria: (a) it produces effects in all circumstances; (b) it creates emotional consequences; (c) it influences cognitive processes; (d) it produces negative effects when the need is not met; (e) it applies to all individuals; (f) it affects several behaviors.

To our knowledge, two conceptual analyzes have attempted to identify the definitional attributes of school belonging, that is, the element most frequently cited to describe the essence of a concept. The first conceptual analysis was conducted in the public health sector. Hagerty, Lynch-Sauer, Patusky, Bouwsema, and Collier (1992) determined that belonging consists of two definitional attributes: (1) commitment, and (2) harmonization. While the first attribute relates to the experience of being valued and accepted by others, the second refers to the perception that the person harmonizes his/her individual characteristics and his/her values with those of the members of the group. Despite a useful methodology to delineate the essence of a concept, this study does not take into account the definitions associated with belonging in the school context.

The second conceptual analysis takes into account a much wider range of definitions, including those developed for the school context. Using Walker and Avant's (2011) methodology, St-Amand, Bowen, and Lin (2017) identified four definitional attributes: students must (1) feel a positive emotion toward school; (2) maintain positive social relationships with peers and teachers; (3) experiment a synergy (harmonization) and a certain similarity with the members of the group; (4) participate actively in school and classroom activities. Thus, the identification of these four definitional attributes has given rise to a new definition of school belonging:

School belonging is a complex and multidimensional concept that includes an emotional, social, participatory and adaptive dimension. In this context, the sense of school belonging is achieved when students develop positive social relationships with members of the school environment; social relationships characterized by encouragement, valorization, acceptance, support, respect, and friendship. Belonging also refers to positive emotions, which could be described as emotional attachments, more precisely to a feeling of intimacy, feeling part of a 
supportive environment, and a sense of pride in the school. The sense of belonging is characterized by active participation in school activities (e.g., extracurricular activities) and teacher-led activities in the classroom, as well as the adoption of norms, standards, and values conveyed within the socio-educational environment. This feeling refers to the harmonization of the needs and desires of the student to those of the members of the group, an element reflecting the positive adjustment to the school environment (loose translation). (St-Amand, Bowen, \& Lin, 2017, p. 14)

In light of these definitional attributes, the instrument examined in the first study, the Psychological Sense of School Membership (PSSM), measures many of these attributes, such as the quality of social relations, students' positive emotions/perceptions, and their involvement in the school environment.

\section{Study 1 \\ EXPLORATORY AND CONFIRMATORY FACTOR ANALYSES}

Carol Goodenow (1993b) developed the PSSM (Psychological Sense of School Membership scale) to measure the sense of school belonging, which is a key concept for students' adjustment and engagement (St-Amand, Bowen, \& Lin, 2017). Goodenow's PSSM is based on the work of Wehlage et al. (1989), who published a theoretical model on dropout prevention. In this model, for the very first time, developing a sense of belonging toward school was shown as critical for retaining students who are considered at risk of dropping out before obtaining their diploma. This model has been the source of several subsequent studies on belonging in school environments and especially to the work leading to the development of the PSSM scale (Goodenow, 1993a, 1993b; Goodenow \& Grady, 1993), which is currently one of the most frequently used instruments in studies dealing with school belonging.

By considering the multidimensional nature of the sense of school belonging, Goodenow developed items reflecting concepts such as acceptance, respect, and encouragement. Items were also developed to measure belonging in a more general perspective that characterizes the link between the student and his/her school. To avoid so-called automatic responses from students, a few items were developed in a negative form. The PSSM consists of 18 self-reported items (Table 1) describing different characteristics of students' school environment. The instrument includes 18 items measured on a five-point Likert-Scale response scale ( $1=$ not at all true and $5=$ completely true).

Besides the PSSM (Psychological Sense of School Membership), other instruments are used to measure school belonging. Janosz, Georges and Parent (1998) developed the Questionnaire on the socio-educational environment (QES), which includes several scales in French, one of which measures the climate (feeling) of belonging to the school. As a whole, the QES is a measurement instrument aimed at documenting the quality of the school environment, while contributing to the study of the influence of the school environment on academic performance and students' adaptation to school (Janosz et al., 2007). The items used to measure school belonging mainly refer to the emotional dimension of the feeling of belonging: "I am proud to be a student of this school"; "I really feel at home in this school"; "I would rather be in another school"; "This school is important to me".

Midgley et al. (2000) developed the Patterns of Adaptive Learning Scales (PALS) in 1998 at the University of Michigan. The Patterns of Adaptive Learning Scales (PALS) are designed to explore the relationships between student motivation, affect, and behavior and the learning environment. In validating their theoretical model, Roeser, Midgley and Urdan (1996) used a few items from the PALS to measure the feeling of belonging. The items on this scale measured exclusively the emotional dimension of the feeling of belonging (St-Amand, Bowen \& Lin, 2017): "I feel like I belong in this school "; "I feel like I am successful in this school"; "I feel like I matter in this school"; "I do not feel I am important in this school". 
Table 1. Psychological Sense of School Membership (Goodenow, 1993a) French translation by Boily and Bowen, in Boily, unpublished manuscript, 2002.

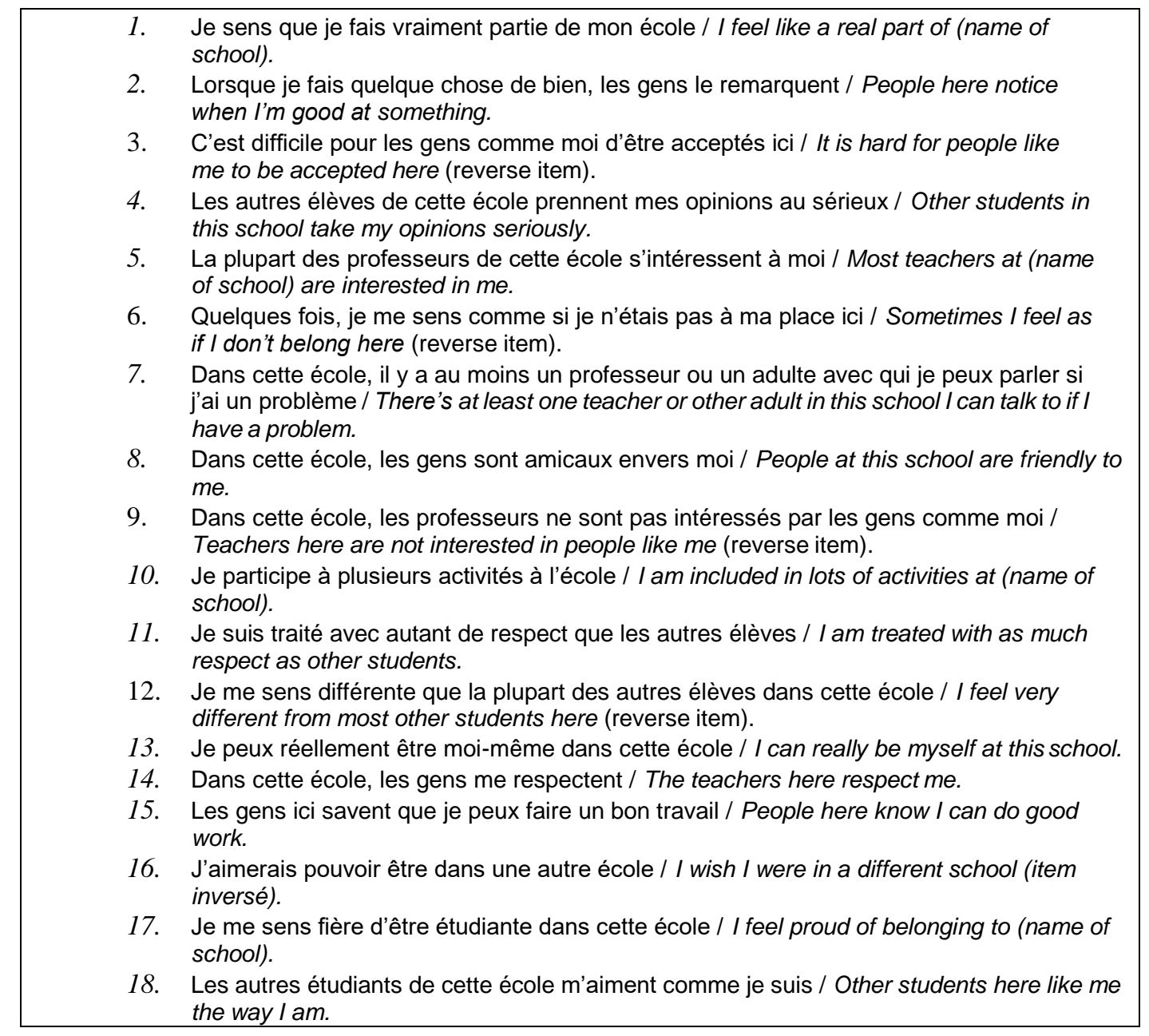

The PSSM has been the subject of a few validation studies in recent years. A review of the literature has identified 12 studies (Table 2 is derived from the work of Abubakar et al., 2016). Some of these studies used only exploratory factor analysis, while others used confirmatory factor analysis. Table 2 reports these studies, as well as the year of publication, the countries where the studies were conducted, the type of sample, and the main results.

Table 2. Validation Studies Using the PSSM

\begin{tabular}{|l|l|l|l|l|}
\hline $\begin{array}{l}\text { First } \\
\text { author }\end{array}$ & $\begin{array}{l}\text { Year of } \\
\text { Publication }\end{array}$ & Country & Sample & Main Result \\
\hline Goodenow & $1993 a$ & United Sates & $\begin{array}{l}1357 \text { high } \\
\text { school student }\end{array}$ & $\begin{array}{l}\text { Good internal } \\
\text { consistency Correlations } \\
\text { largely in the } \\
\text { hypothesized directions } \\
\text { No factorial analysis } \\
\text { reported }\end{array}$ \\
\hline Hagborg & 1994 & United Sates & $\begin{array}{l}30 \text { high school } \\
\text { students }\end{array}$ & $\begin{array}{l}\text { EFA } \\
\text { ldentified three factors: } \\
\text { Belonging } \\
\text { Rejection } \\
\text { Acceptance }\end{array}$ \\
\hline Hagborg & 1998 & United Sates & $\begin{array}{l}120 \text { high school } \\
\text { and } \\
\text { elementary }\end{array}$ & $\begin{array}{l}\text { EFA } \\
\text { Excluded some items } \\
\text { All items were positively }\end{array}$ \\
\hline
\end{tabular}




\begin{tabular}{|c|c|c|c|c|}
\hline & & & school students & worded \\
\hline O'Farrell & 2003 & United Sates & $\begin{array}{l}543 \text { elementary } \\
\text { school students }\end{array}$ & $\begin{array}{l}\text { EFA } \\
\text { Used it alongside other } \\
\text { scales Identified three } \\
\text { factors that included } \\
\text { items from the other } \\
\text { scales }\end{array}$ \\
\hline Cheung & 2003 & China & $\begin{array}{l}547 \text { elementary } \\
\text { school students }\end{array}$ & $\begin{array}{l}\text { EFA } \\
\text { Two-factor solution: } \\
\text { Sense of belonging } \\
\text { Sense of rejection }\end{array}$ \\
\hline Cheung & 2004 & China & $\begin{array}{l}220 \text { elementary } \\
\text { school students }\end{array}$ & $\begin{array}{l}\text { EFA } \\
\text { Two-factor solution: } \\
\text { Sense of belonging } \\
\text { Sense of rejection }\end{array}$ \\
\hline You & 2011 & Australia & $\begin{array}{l}504 \text { high school } \\
\text { students }\end{array}$ & $\begin{array}{l}\text { EFA-CFA } \\
\text { Excluded some items } \\
\text { Identified three factors: } \\
\text { Caring relationships with } \\
\text { teachers } \\
\text { Acceptance Rejection }\end{array}$ \\
\hline Togari & 2011 & Japan & $\begin{array}{l}1539 \text { high school } \\
\text { students }\end{array}$ & $\begin{array}{l}\text { CFA } \\
\text { Reduced items Identified } \\
\text { three factors: } \\
\text { Acceptance by teachers } \\
\text { Acceptance by students } \\
\text { Belonging }\end{array}$ \\
\hline Ye & 2014 & United States & $\begin{array}{l}890 \text { high school } \\
\text { students }\end{array}$ & $\begin{array}{l}\text { EFA-CFA } \\
\text { Factorial structure } \\
\text { influenced by negatively } \\
\text { worded items Identifies } \\
\text { three substantive } \\
\text { factors: } \\
\text { Identification and } \\
\text { participation in school } \\
\text { Perceptions of fitting in } \\
\text { with peers } \\
\text { Generalized connection } \\
\text { with peers }\end{array}$ \\
\hline Gaete & 2016 & Chile & $\begin{array}{l}1250 \text { elementary } \\
\text { and } \\
\text { high school } \\
\text { students }\end{array}$ & $\begin{array}{l}\text { EFA-CFA } \\
\text { Identified one factor } \\
\text { (without the negative } \\
\text { worded items) }\end{array}$ \\
\hline Abubakar & 2016 & $\begin{array}{l}\text { Netherlands, } \\
\text { Kenya, } \\
\text { Indonesia, } \\
\text { Spain }\end{array}$ & $\begin{array}{l}1928 \text { high } \\
\text { school students }\end{array}$ & $\begin{array}{l}\text { CFA-MGFA } \\
\text { The relationship } \\
\text { between the latent } \\
\text { structure of PSSM and } \\
\text { life satisfaction was } \\
\text { similar across context }\end{array}$ \\
\hline Wagle & 2018 & $\begin{array}{l}\text { USA, United } \\
\text { Kingdom, } \\
\text { China }\end{array}$ & $\begin{array}{l}2482 \text { elementary } \\
\text { students }\end{array}$ & $\begin{array}{l}\text { EFA, CFA-MGFA } \\
\text { Partial invariance across } \\
\text { all three samples and full } \\
\text { invariance across } \\
\text { pairwise samples } \\
\text { (United States and } \\
\text { United Kingdom; United } \\
\text { Kingdom and China) } \\
\text { was found }\end{array}$ \\
\hline
\end{tabular}

Note: PSSM = Psychological Sense of School Membership; CFA = Confirmatory Factor Analysis; EFA = Exploratory Factor Analysis; MGFA = Multigroup Factor Analysis.

\section{Rational of the study}

Researchers frequently use the PSSM to measure students' sense of school belonging and to examine the quality of the student's connection to their school. Nevertheless, published studies validating the factorial structure of the PSSM have not yet validated its 
French version and suggested similar and divergent factorial results. For example, validation studies using samples of elementary students resulted in a one-factor structure (Gaete et al., 2016) and two-factor structure (Cheung, 2004; Cheung \& Hui, 2003); in turn, validation studies using samples of high school students resulted in a three- factor structure (Hagborg, 1994; Ye \& Wallace, 2014; You et al., 2011). Most of the studies conducted with samples of high school students included preadolescents or elementary students (Abubakar et al., 2016; Ye \& Wallace, 2014; You et al., 2011), which might hinder our capacity to properly identify the factorial structure of the PSSM with older adolescents. As for the invariance of the PSSM instrument, studies are limited and not much is known so far. In fact, invariance tests were only conducted to compare the PSSM across different cultures (Abubakar et al., 2016; Wagle et al., 2018) (see Table 2 for results). Although the scientific literature presents belonging as an innate need that is shared by all (Baumeister \& Leary, 1995), we do not know to this day if the PSSM instrument is invariant regarding the gender of the participants, and that, specifically, in a context (during high school) where dropout rates are high (Freeman \& Simonsen, 2015; Stearns \& Glennie, 2006) and where girls outperform boys in primary school through to college (Almås et al., 2016). Considering that girls usually score higher than boys on the PSSM scale at the high school level, it is relevant to conduct invariance tests with regard to the gender of the participants (Boily, 2002; St-Amand, 2016).

\section{Objective of the first study}

In light of the above, the present study aims to conduct additional analyses on the French version of the PSSM through an examination of its factorial structure as well as its invariance with regards to the gender of the participants.

\section{Methodology \\ Participants and data collection}

Data used in study 1 and 2 was collected in four public schools distributed in the city of Montreal (Quebec, Canada). More precisely, 1600 students were asked to complete a selfreported questionnaire that allowed to measure multiple sub-dimensions that are associated to a sense of school belonging. Of this potential sample, 831 students (596 girls, 235 boys) provided a usable data (target age group: 11th grade) which has been, in a first round of analysis, submitted to factors analyses and invariance tests, performed with the version 26 of the IBM-SPSS software.

\section{Data analyses}

The use of multigroup confirmatory factor analysis is an innovative approach that can be used to examine whether items and the factorial structure of a measurement instrument are equivalent across different groups (Brown, 2015, 2006; Byrne, 2004, 2008). According to Kline (2011, p. 251), "Measurement invariance (equivalence) concerns whether scores from the operationalization of a construct have the same meaning under different conditions." The use of multigroup confirmatory factor analysis makes it possible to examine all aspects regarding the invariance of an instrument (Brown, 2006, 2015). It should be mentioned that missing values (they were missing completely at random in our case) were handled by using maximum likelihood estimation (Tabachnick and Fidell, 2013).

In order to test the invariance of an instrument, a series of hierarchical steps need to be conducted. It first starts with the determination of a baseline model for each group separately; this model is the best one in terms of fit, parsimony, and substantive meaningfulness. Following the completion of this preliminary task, tests for the equivalence of parameters are conducted across groups. More precisely, it consists of testing the equivalence of factor loadings of each observed measure. Once it is clear which measures are group-invariant, it allows us to equally constrain these parameters and conduct subsequent tests. The parameters known to be group-invariant are cumulatively constrained equal. As Byrne (2016, p. 230) recommends: " $\{\ldots\}$ the process of determining nonequivalence of measurement and structural parameters across groups involves the testing of a series of increasingly restrictive hypotheses." To determine which factor loading is invariant, we will examine the results of the $\chi^{2}$-difference test.

In this study, different fit indices are needed such as the chi-square ( $\mathrm{X} 2)$, CFI (Comparative 
Fit Index), and RMSEA (Root Mean Square Error of Approximation). Hu and Bentler (1999) suggest that a good model should have acceptable values for the majority of these indices. The global fit index that we used is the chi-square $(x 2)$ (also called likelihood ratio chi-square or generalized likelihood ratio); a nonsignificant value means that the model fits the data (Tabachnick \& Fidell, 2013). However, the chi-square is mostly significant with a sample of more than 400 participants; in this case, other fit indices are needed such as the Comparative Fit Index (CFI) in which values above 0.95 mean that the model fits the data well (Kline, 2011). Root Mean Square Residual Error of Approximation (RMSEA) should have a value lower than 0.06 to be considered a close fit and around 0.08 to be considered an acceptable fit (Browne \& Cudeck, 1993).

\section{Descriptive statistics}

Preliminary analyses indicated acceptable data distribution, homogeneity of variance, and the absence of multicollinearity. The following table presents the means, standard deviations, kurtosis, and skewness of the 18 PSSM items.

Table 3. Psychological Sense of School Belonging (PSSM)

\begin{tabular}{|c|c|c|c|c|c|}
\hline Items & $\underline{\mathrm{M}}$ & $\underline{\mathrm{SD}}$ & $\underline{\mathrm{K}}$ & $\underline{\mathrm{S}}$ & $\underline{N}$ \\
\hline 1.I feel like a real part of (name of school). & 3.64 & 0.997 & 0.307 & -0.693 & 831 \\
\hline $\begin{array}{l}\text { 2.People here notice when l'm good at } \\
\text { something. }\end{array}$ & 3.37 & 0.975 & -0.134 & -0.85 & 831 \\
\hline $\begin{array}{l}\text { 3.It is hard for people like me to be accepted } \\
\text { here (reverse coding). }\end{array}$ & 4.28 & 0.976 & 1.681 & -1.446 & 831 \\
\hline $\begin{array}{l}\text { 4.Other students in this school take my } \\
\text { opinions seriously. }\end{array}$ & 3.61 & 0.927 & 0.495 & -0.673 & 831 \\
\hline $\begin{array}{l}\text { 5.Most teachers at (name of school) are } \\
\text { interested in me. }\end{array}$ & 3.49 & 1.001 & 0.065 & -0.576 & 831 \\
\hline $\begin{array}{l}\text { 6.Sometimes I feel as if I don't belong } \\
\text { here (reverse coding). }\end{array}$ & 3.70 & 1.253 & -0.547 & -0.682 & 831 \\
\hline $\begin{array}{l}\text { 7.There's at least one teacher or other adult in } \\
\text { this school I can talk to if I have a problem. }\end{array}$ & 3.95 & 1.295 & 0.070 & -1.112 & 831 \\
\hline 8.People at this school are friendly to me. & 4.07 & 0.805 & 1.209 & -0.869 & 831 \\
\hline $\begin{array}{l}\text { 9.Teachers here are not interested in } \\
\text { people like me (reverse coding). }\end{array}$ & 4.18 & 1.024 & 1.222 & -1.297 & 831 \\
\hline $\begin{array}{l}10.1 \text { am included in lots of activities at } \\
\text { (name of school). }\end{array}$ & 2.96 & 1.235 & -0.895 & 0.039 & 831 \\
\hline $\begin{array}{l}\text { 11. I am treated with as much respect as } \\
\text { other students. }\end{array}$ & 4.27 & 0.885 & 2.000 & -1.487 & 831 \\
\hline $\begin{array}{l}\text { 12.I feel very different from most other } \\
\text { students here (reverse coding). }\end{array}$ & 3.54 & 1.324 & -0.912 & -0.502 & 831 \\
\hline 13.I can really be myself at this school. & 3.75 & 1.176 & -0.207 & -0.779 & 831 \\
\hline 14. The teachers here respect me. & 4.15 & 0.891 & 0.988 & -1.032 & 831 \\
\hline 15.People here know I can do good work. & 4.10 & 0.847 & 0.835 & -0.879 & 831 \\
\hline $\begin{array}{l}16.1 \text { wish I were in a different school } \\
\text { (reverse coding). }\end{array}$ & 3.90 & 1.262 & -0.063 & -0.992 & 831 \\
\hline $\begin{array}{l}\text { 17. I feel proud of belonging to (name of } \\
\text { school). }\end{array}$ & 3.54 & 1.146 & -0.265 & -0.601 & 831 \\
\hline 18.Other students here like me the way I am. & 4.06 & 0.896 & 1.495 & -1.104 & 831 \\
\hline
\end{tabular}

$\mathrm{M}=$ Mean; SD = Standard deviation; $\mathrm{K}=$ Kurtosis; $\mathrm{S}=$ Skewness; $\mathrm{N}=$ Participants

\section{Results}

An exploratory factor analysis with a promax rotation was first carried out on the entire sample. Then, a preliminary single-group confirmatory factor analysis was conducted to examine the factorial structure of the PSSM instrument for the full-sample data. Further, two separate single-group confirmatory factor analyses were conducted for boys and girls. 
Finally, a multigroup factor analysis was conducted simultaneously across boys and girls to examine the construct validity of the PSSM across the two samples (boys and girls). In order to identify factor loadings of the PSSM items found to be invariant and noninvariant, chisquare difference tests were carried out on an item-by-item basis.

\section{Exploratory factor analysis}

Our factorial structure revealed that the French version of the PSSM was made up of four scales (or dimensions) (see Table 4). As for other studies, the PSSM did not show a threefactor and two-factor structure. When we fixed the factorial structure to three and two factors, most of the items of the PSSM overlapped. We only present in that table the scores which loaded 0.30 and over. Scale 1 (peers' relationships) is comprised of five items which explain $5.775 \%$ of the variance. Scores for those items ranged from .321 to .738. Scale 2 (relations with teachers) consists of a group of six items and explains $34.645 \%$ of the variance. For that scale, scores of items were between .311 and .862. Scale 3 (sense of acceptance) is a group of three items and explains $3.001 \%$ of the variance, with scores ranging between .596 and .690. Finally, Scale 4 (sense of attachment) is made of four items explaining $4.218 \%$ of the variance with scores of .369 to .749. Standardized Cronbach's alphas ranged between .720 and .780 for the four scales, which explained $47.639 \%$ of the variance.

Table 4. Exploratory Factor Analysis 11th Grade Students $(n=831)$

\begin{tabular}{|c|c|c|c|c|}
\hline Items & $\begin{array}{l}\text { Scale } 1 \\
\text { Peers' } \\
\text { relationships }\end{array}$ & $\begin{array}{l}\text { Scale } 2 \\
\text { Teacher-student } \\
\text { relationships }\end{array}$ & $\begin{array}{c}\text { Scale } 3 \\
\text { Sense of } \\
\text { acceptance }\end{array}$ & $\begin{array}{l}\text { Scale } 4 \\
\text { Sense of } \\
\text { attachment }\end{array}$ \\
\hline $\begin{array}{l}\text { 2.People here notice when } \\
\text { I'm good at something. }\end{array}$ & .321 & & & \\
\hline $\begin{array}{l}\text { 4.Other students in this } \\
\text { school take my opinions } \\
\text { seriously. }\end{array}$ & .590 & & & \\
\hline $\begin{array}{l}\text { 8.People at this school are } \\
\text { friendly to me. }\end{array}$ & .667 & & & \\
\hline $\begin{array}{l}13 . I \text { can really be myself at } \\
\text { this school. }\end{array}$ & .340 & & & \\
\hline $\begin{array}{l}\text { 18.Other students here like } \\
\text { me the way I am. }\end{array}$ & .738 & & & \\
\hline $\begin{array}{l}\text { 5.Most teachers at (name } \\
\text { of school) are interested in } \\
\text { me. }\end{array}$ & & .643 & & \\
\hline $\begin{array}{l}\text { 7.There's at least one } \\
\text { teacher or other adult in } \\
\text { this school I can talk to if I } \\
\text { have a problem. }\end{array}$ & & .311 & & \\
\hline $\begin{array}{l}\text { 9. Teachers here are not } \\
\text { interested in people like me } \\
\text { (reverse coding). }\end{array}$ & & .706 & & \\
\hline $\begin{array}{l}\text { 14. The teachers here } \\
\text { respect me. }\end{array}$ & & .862 & & \\
\hline $\begin{array}{l}11 . I \text { am treated with as } \\
\text { much respect as other } \\
\text { students. }\end{array}$ & & .425 & & \\
\hline $\begin{array}{l}\text { 15.People here know I can } \\
\text { do good work. }\end{array}$ & & .460 & & \\
\hline $\begin{array}{l}\text { 3.It is hard for people like } \\
\text { me to be accepted here } \\
\text { (reverse coding). }\end{array}$ & & & .596 & \\
\hline 6.Sometimes I feel as if I & & & .604 & \\
\hline
\end{tabular}




\begin{tabular}{|c|c|c|c|c|}
\hline $\begin{array}{l}\text { don't belong here (reverse } \\
\text { coding). }\end{array}$ & & & & \\
\hline $\begin{array}{l}12 . I \text { feel very different from } \\
\text { most other students here } \\
\text { (reverse coding). }\end{array}$ & & & .690 & \\
\hline $\begin{array}{l}\text { 1. I feel like a real part of } \\
\text { (name of school). }\end{array}$ & & & & .749 \\
\hline $\begin{array}{l}10.1 \text { am included in lots of } \\
\text { activities at (name of } \\
\text { school). }\end{array}$ & & & & .369 \\
\hline $\begin{array}{l}\text { 17. I feel proud of } \\
\text { belonging to (name of } \\
\text { school) }\end{array}$ & & & & .691 \\
\hline $\begin{array}{l}16 . I \text { wish I were in a } \\
\text { different school (reverse } \\
\text { coding). }\end{array}$ & & & & .507 \\
\hline Eigenvalue (\% of variance) & $\begin{array}{c}1.040 \\
(5.775 \%) \\
\end{array}$ & $6.236(34.645 \%)$ & $\begin{array}{c}0.540 \\
(3.001 \%) \\
\end{array}$ & $\begin{array}{c}0.759 \\
(4.218 \%) \\
\end{array}$ \\
\hline $\begin{array}{r}\text { Standardized Cronbach's } \\
\text { alpha }\end{array}$ & .774 & .780 & .720 & .722 \\
\hline
\end{tabular}

\section{Preliminary single-group confirmatory factor analysis for the full-sample data}

First, a preliminary single-group confirmatory factor analysis was conducted using the fullsample data $(n=831$ ) (Model A, in Table 5). In Model A, each item of the PSSM instrument was specified as an indicator for only one factor. The fit indices for the hypothesized fourfactor model (Model A) with 18 items were as follows: $X^{2}=875.104$, df $=129, p=<.001$, $\mathrm{CFI}=.869$, RMSEA $=.083$, and $\mathrm{X}^{2} / \mathrm{df}=6.784$.

The model was re-specified after examining the modification indices, the standardized regression weights (factor loadings), and the squared multiple correlations of the items. Based on the modification indices, correlated errors between item 16 and item 6 , item 8 and item 11, item 11 and item 7, item 11 and item 5 , and item 9 and item 5 were added to the fitted model. According to Brown (2006), when items in a survey are similarly worded, their errors might be correlated, which was the case with these items. This re- specified model was named Model B (Table 5). Compared to Model A, fit indices showed that the re-specified model resulted in a significant improvement of fit.

To improve the fit indices, the model was specified again. Four items (items 10, 4, 7, and 12), showing low standardized regression weight (less than .50) and squared multiple correlations (less than .15), were trimmed off the model. Three additional correlated errors were added to the model (correlated errors between items 13 and 16, between 18 and 8, and between items 2 and 5). This re-specified model was named Model $C$. The fit indices for Model C were as follows: $\mathrm{X} 2=374.046, \mathrm{df}=64, p=<.001, \mathrm{CFI}=.950, \mathrm{RMSEA}=.065$, and $\mathrm{X} 2 / \mathrm{df}=5.844$. Overall, the hypothesized four-factor model exhibited a close fit.

Table 5. Summary of Fit Indices from Confirmatory Factor Analysis for Full-Sample Data ( $n$ $=831$ )

\begin{tabular}{|l|c|c|c|c|c|}
\hline Model & $\mathbf{X}^{2}(\mathbf{d f})$ & $\boldsymbol{p}$ & RMSEA & $\mathbf{X}^{2} / \mathbf{d f}$ & CFI \\
\hline Model A & $\begin{array}{c}875.104 \\
(129)\end{array}$ & $<.001$ & .083 & 6.784 & .869 \\
\hline Model B & $\begin{array}{c}706.005 \\
(124)\end{array}$ & $<.001$ & .075 & 5.694 & .898 \\
\hline Model C & $\begin{array}{c}374.046 \\
(64)\end{array}$ & $<.001$ & .076 & 5.844 & .935 \\
\hline
\end{tabular}

\section{Preliminary single-group analyses for boys}

The above three single-group CFA models were fit using the boys-sample data only ( $\mathrm{n}=$ 
235). Table 6 presents the results from the confirmatory factor analysis for the boys- sample data. The fit indices for Model $C$ were $x 2=161.935$, df $=64, p=<.001, \mathrm{CFI}=.914$, RMSEA $=.081$, and $x 2 / d f=2.530$. These fit indices suggest that the model exhibited a borderline fit.

Table 6. Summary of Fit Indices from Confirmatory Factor Analysis for Boys $(n=235)$

\begin{tabular}{|l|c|c|c|c|c|}
\hline Model & $\mathbf{X}^{2}(\mathbf{d f})$ & $\boldsymbol{p}$ & $\mathbf{R M S E A}$ & $\mathbf{X}^{2} / \mathbf{d f}$ & CFI \\
\hline Model A & $\begin{array}{c}339.839 \\
(129)\end{array}$ & $<.001$ & .084 & 2.634 & .849 \\
\hline Model B & $\begin{array}{c}306.157 \\
(124)\end{array}$ & $<.001$ & .079 & 2.469 & .870 \\
\hline Model C & $\begin{array}{c}161.935 \\
(64)\end{array}$ & $<.001$ & .081 & 2.530 & .914 \\
\hline
\end{tabular}

\section{Preliminary single-group analyses for girls}

Next, the above three single-group CFA models were fitted using the girls-sample data only $(n=596)$. The summary fit indices derived from the confirmatory factor analysis for the girlssample data are presented in Table 7. The fit indices for Model C were $X 2=338.992, \mathrm{df}=64$, $p=<.001, \mathrm{CFI}=.926$, RMSEA $=.085$, and $\mathrm{x} 2 / \mathrm{df}=5.428$. These fit indices suggest that the model exhibited a borderline fit.

Table 7. Summary of Fit Indices from Confirmatory Factor Analysis for Girls $(n=596)$

\begin{tabular}{|l|c|c|c|c|c|}
\hline Model & $\mathbf{X}^{2}(\mathbf{d f})$ & RMSEA & $\boldsymbol{p}$ & $\mathbf{X}^{2} \mathbf{d f}$ & $\mathbf{C F I}$ \\
\hline Model A & $\begin{array}{c}766.794 \\
(129)\end{array}$ & .091 & $<.001$ & 5.944 & .857 \\
\hline Model B & $\begin{array}{c}616.097 \\
(124)\end{array}$ & .082 & $<.001$ & 4.969 & .890 \\
\hline Model C & $\begin{array}{c}338.992 \\
(64)\end{array}$ & .085 & $<.001$ & 5.428 & .926 \\
\hline
\end{tabular}

\section{Multigroup confirmatory factor analysis}

The single-group CFA model using the full-sample data exhibited a close fit. The twoseparate single-group CFA models indicated that the factorial structure of the PSSM instrument exhibited a borderline fit overall; the results indicated a similar pattern for boys and girls. We then conducted a multigroup CFA to test whether the factorial structure of the PSSM was invariant across boys and girls. Table 8 presents summary fit indices of three nested models for the multigroup confirmatory factor analysis in order to identify the sources of invariance.

Table 8. Fit Indices of the Nested Models of Multigroup Confirmatory Factor analysis ( $n=$ 831)

\begin{tabular}{|l|c|c|c|c|c|}
\hline Model & $\mathbf{X}^{2}(\mathbf{d f})$ & $\mathbf{R M S E A}$ & $\boldsymbol{p}$ & $\mathbf{X}^{2} \mathbf{d f}$ & $\mathbf{C F I}$ \\
\hline Unconstrained model & $\begin{array}{c}500.981 \\
(128)\end{array}$ & .059 & $<.001$ & 3.914 & .923 \\
\hline $\begin{array}{l}\text { Measurement weights } \\
\text { model }\end{array}$ & $\begin{array}{c}526.856 \\
(138)\end{array}$ & .058 & $<.001$ & 3.818 & .920 \\
\hline $\begin{array}{l}\text { Structural covariances } \\
\text { model }\end{array}$ & $\begin{array}{c}548.423 \\
(169)\end{array}$ & .057 & $<.001$ & 3.706 & .918 \\
\hline
\end{tabular}

\section{Partial measurement invariance}

According to our results, the measurement weights model analysis indicated that some equality constraints of factor loadings did not hold across boys and girls. Therefore, chisquare difference tests were conducted on an item-by-item basis in the context of partial measurement invariance in order to identify factor loadings of which items were equivalent and which were nonequivalent across boys and girls; a nonsignificant chi-square difference test meant that the factor loading of that item was not statistically different across boys and girls. 
We had to proceed this way until all of the noninvariant items were identified; we also had to re-run multigroup CFA with different marker indicators (Brown, 2006). Results of chi-square difference tests indicated that the factor loadings of items $6,8,13$, and 15 (see Table 9) were nonequivalent and that all of the other items of the PSSM were invariant across boys and girls.

Table 9. Nonequivalent Items of the PSSM in Regards to the Gender of the Participants

6.Sometimes I feel as if I don't belong here (reverse coding).

8.People at this school are friendly to me.

13. I can really be myself at this school.

15.People here know I can do good work.

\section{Discussion}

The present study aimed at conducting additional analyses on the French version of the PSSM through an examination of its factorial structure as well as its invariance across boys and girls of 11th grade. Our results demonstrated four clear-cut dimensions of belonging (1. teacher-student relationships; 2. peers' relationships; 3 . sense of acceptance; 4 . sense of attachment), which might be explained by our sample that consisted 11th grade students only (no elementary students nor preadolescents included in our sample).

The first factor, labeled peers' relationships, has two items reflecting precisely students' relationships with peers (e.g., other students in this school take my opinions seriously; other students here like me the way I am). Although written to include all members of the school environment, students may interpret two other items with regard to the relationships they have with their peers only (e.g., people at this school are friendly to me; people here notice when I'm good at something). One could argue that the word "people" might confuse students. Also, being able to be yourself in the school environment may refer to the respect that prevails between peers (e.g., I can really be myself at this school). As a matter of fact, Goodenow (1993a) defines belonging as a feeling that implies respect.

The second factor, labeled teacher-student relationships, refers to concepts such as justice, recognition and respect between the teacher and the student (e.g., the teachers here respect me; people here know I can do good work; I am treated with as much respect as other students). Also, the teacher's support and the teacher's capacity to interact with students seem to be an important dimension of this factor (e.g., most teachers at (name of school) are interested in me; teachers here are not interested in people like me (reverse coding)

The third factor, labeled sense of acceptance, mirrors the student's perception toward the treatment he or she receives from the school environment (e.g., it is hard for people like me to be accepted here (reverse coding)), and the degree of fit between the student and his or her school (I feel very different from most other students here (reverse coding); sometimes I feel as if I don't belong here (reverse coding)).

The fourth factor, the sense of attachment, echoes students' positive feelings about the school environment. These feelings refer in part to a general sense of connection to school (I feel like a real part of (name of school); I wish I were in a different school (reverse coding)) and to students' achievement emotions (I feel proud of belonging to (name of school); I am included in lots of activities at (name of school)) (Pekrun, Elliot, \& Maier, 2006).

The results of multigroup CFA analyses revealed that four-factor loadings were not upheld across boys and girls of 11th grade. Results of chi-square difference tests revealed that the factor loadings of items $6,8,13$, and 15 were nonequivalent, and the factor loadings of other items were invariant across boys and girls. In light of the above, our results indicated that the PSSM was a partially invariant measurement instrument. These four nonequivalent items (items 6, 8, 13, and 15) covered the feeling of acceptance (item 6), peers' relationships (items 8 and 13), and relations with teachers (item 15). The reasons for nonequivalence in factor loadings for these items might be due to the level of belonging between boys and girls. Knowing that more boys dropout of high school and that a low level of belonging plays an important role in that process (Finn, 1989; Wehlage et al., 1989), we believe it may explain why some factor loadings were nonequivalent on the measure of belonging across boys and 
girls of that age. Further research is needed with older samples of adolescents; also, future research might use item response theory, which is an important method of assessing the validity of measurement scales that is underutilized in the field of educational psychology.

\section{Study 2}

\section{APPLICATION OF THE FACTOR SOLUTION WITH A SAMPLE OF AT-RISK STUDENTS}

Is excellent education for all America's children a good investment? This is the question many researchers attempted to answer at the First Annual Teachers College Symposium on Educational Equity in the United States in 2005 (Belfield \& Levin, 2005). As part of this symposium, many economists and social scientists sought to quantify the social costs of inadequate education related to dropping out. Five broad categories of social consequences were associated with dropping out of school such as tax and financial losses (Rouse, 2007), decreased quality of health (Muennig, 2007), rising crime rate and costs related to the justice system (Moretti, 2007), and increased welfare benefits (Waldfogel, Garfinkel, \& Kelly, 2007). Considering these negative consequences, school dropout is still today an important issue that many countries have to deal with because a significant number of young people quit school before earning their high school diploma (Archambault et al., 2016). The rate of dropout is even higher among low-income students (Brooks-Gunn \& Duncan, 1997).

The factors that lead students to disengage from school to the point of dropping out are numerous. These factors are at the individual, family, community, sociological, socioeconomic, and institutional levels (Rumberger, 2011). In fact, a low level of belonging to school is an important factor that leads students to dropout (Berktold, Geis, \& Kaufman, 1998; Christenson \& Thurlow, 2004). We will therefore evaluate the predictive potential of the PSSM (Psychological Sense of School Membership). Predictive validity is a specific type of validity that can answer the following question in the case of this study: does this instrument measure what it is supposed to measure (study 1) and can the results be used to predict high school dropout? (study 2).

That said, in recent years, in the province of Quebec (Canada), funding programs have been developed to generate knowledge that will lead to the development of dropout prevention interventions as well as strategies aimed to enhance and sustain school success. A group of researchers (Janosz, Deniger, Roy, Lacroix, Fallu, Langevin, \& Le Blanc, 2001) has obtained funds to evaluate short and mid-term effects of such programs and also, to better understand the factors responsible for their successes or failures. We have an interest in one of these projects in which the integral PSSM questionnaire was completed by a cohort of students. This was an excellent opportunity for us to see how the PSSM behaves with at-risk students from special high schools as it has never been used in this context to this day.

\section{Method}

\section{Participants}

A total of 289 at-risk students answered the questionnaires, of which approximately $60 \%$ were boys and 40\% girls. Aged $12-18$ years $(M=15.28 ; S D=1.69)$, these students attended special high schools located in underprivileged environments in the city of Montreal. This sub-sample was cumulating several risk factors that could have led them to drop out of school (e.g., negative school experience, fragile psychosocial adjustment, etc.). The students were out of the regular school system and were benefiting from a special adaptative educational environment (small and stable group of students, less but more available teachers, special academic and behavioral supervision).

\section{Instruments}

School belonging was measured with the PSSM (Psychological Sense of School Membership) scale developed by Goodenow at Tufts University in Boston (1993a). The scale consists of 18 questions that are answered on five-point Likert scales ( 1 = Totally False, $5=$ Totally True). Five of those questions are reversed. The PSSM scale has been validated by many researchers so far (see Table 2 in Study 1). Along with the PSSM scores, we used two measures and a classification from the larger questionnaire to be used as control variables in our analysis of variance (ANOVA): Dropout Typology, Dropout Process, and Dropout Status.

\section{Dropout typology}

The Dropout Typology has been elaborated by Janosz, Le Blanc, Boulerice, and Tremblay 
(2000) from the MASPAQ (Mesures de l'adaptation sociale et personnelle pour les adolescents québécois, in English: Measures of social and personal adjustment for Quebec adolescents) instrument which was designed by Le Blanc (1998). The MASPAQ has shown to have relatively high reliability (LeBlanc et al., 1996; McCuish et al. 2015) and has been used by many researchers so far (Fallu et al., 2012; Janosz et al., 1998). The Dropout Typology is not a variable but rather a classification, on a four-item scale, of the students' potential to dropout of school during the year. Items of that scale were: Discreet (high school commitment, good schoolwork, less apparent behavior problems), Disengaged (low school commitment, good schoolwork, less apparent behavior problems), Underperforming (low school commitment, poor schoolwork, less apparent behavior problems), and Unadapted (low school commitment, poor schoolwork, more apparent behavior problems). For the purpose of this study, we recoded the four items in two new categories so that we could use it as a control variable for an analysis of variance. "Less at Risk" were those included in the Discreet group while all students from the three other groups were included in a group labeled "More at Risk".

\section{Dropout process}

The Dropout Process measure indicated, on a four-item scale, the levels at which the students were positioning themselves in their plans for dropping out. Items of the scale were: Precontemplation (has never considered dropping out of school); Contemplation (has considered dropping out of school); Preparation (is considering dropping out of school in the next 30 to 90 days but has not yet started missing school); Action (is considering dropping out of school in the next 30 to 90 days and has started missing school). Here again, we recoded the four items in two new categories. Students in the Precontemplation group were labeled as "Not Engaged" in a Dropout Process while all students from the three other groups were included in a group labeled "Engaged".

\section{Dropout status}

Dropout Status refers to students labeled as "dropouts" in the Action Concertée study, i.e., those who were out of school for more than two consecutive weeks and did not register in another school or another academic program.

\section{Procedure}

Students were asked to answer a questionnaire which contained, among several other measures, the PSSM and the measures presented above. Data were collected over three periods of a single school year: T1 (November), T2 (February), and T3 (May). In the current study, the PSSM behaved the same way as study one regarding its factorial structure.

\section{Result}

\section{Dropout prediction capability of the PSSM}

Most of the time, dropping out of school is not something that students decide on a sudden impulse but is rather the result of a process that can sometimes be quite long (Archambault et al., 2016; Jimerson, Egeland, Sroufe, \& Carlson, 2000). This is why, on top of the Dropout Status measure, we used the Dropout Typology classification and the Dropout Process measure described earlier, to further challenge the predictive value of the PSSM. Since those students were aged from 12 to 18 years old, we first made all the ANOVAs using those three dropout items and the age as independent variables to make sure that age would not cause a bias to the results. Those analyses showed that the age of the students had no single or combined significant effect on the results. Therefore, we only present the results from our analyses which used the three dropout items as independent variables.

For the Dropout Typology measure, Table 10 shows that the PSSM was able to discriminate between "More at Risk" and "Less at Risk" students. With boys and girls together, only the peers' relationships were moderately significant $\left(F_{(2.221)}=6.82 ; p<.05\right)$ in their capacity to discriminate "More at Risk" from "Less at Risk" students. Other results were $\left(F_{(2.221)}=14.41 ; p<.001\right)$ for teacher-student relationships, $\left(F_{(2.221)}=13.43 ; p<.001\right)$ for the sense of acceptance, $\left(F_{(2.221)}=18.80 ; p<.001\right)$ for the sense of attachment to school, and $\left(F_{(2.221)}=18.74 ; p<.001\right)$ for the overall sense of belonging. All the scales of the PSSM were able to significantly discriminate "More at Risk" from "Less at Risk" boys only: $\left(F_{(2.99)}=7.104\right.$; $p<.009)$ for peers' relationships, $\left(F_{(2.99)}=10.762 ; p<.001\right)$ for teacher-student relationships, $\left(F_{(2.99)}=10.708 ; p<.001\right)$ for the sense of acceptance, $\left(F_{(2.99)}=19.161 ; p<.000\right)$ for the 
sense of attachment and, finally, $\left(F_{(2.99)}=17.021 ; p<.000\right)$ for the overall sense of belonging. For girls, only the teacher-student relationships $\left(F_{(2.91)}=7.387 ; p<.008\right)$ and the overall sense of belonging $\left(F_{(2,91)}=4.50 ; p<.037\right)$ were significant in discriminating "More at Risk" students from "Less at Risk".

Table 10. Analysis of Variance (ANOVA) Between the PSSM Scales and the Dropout Typology Classification $(n=223)$

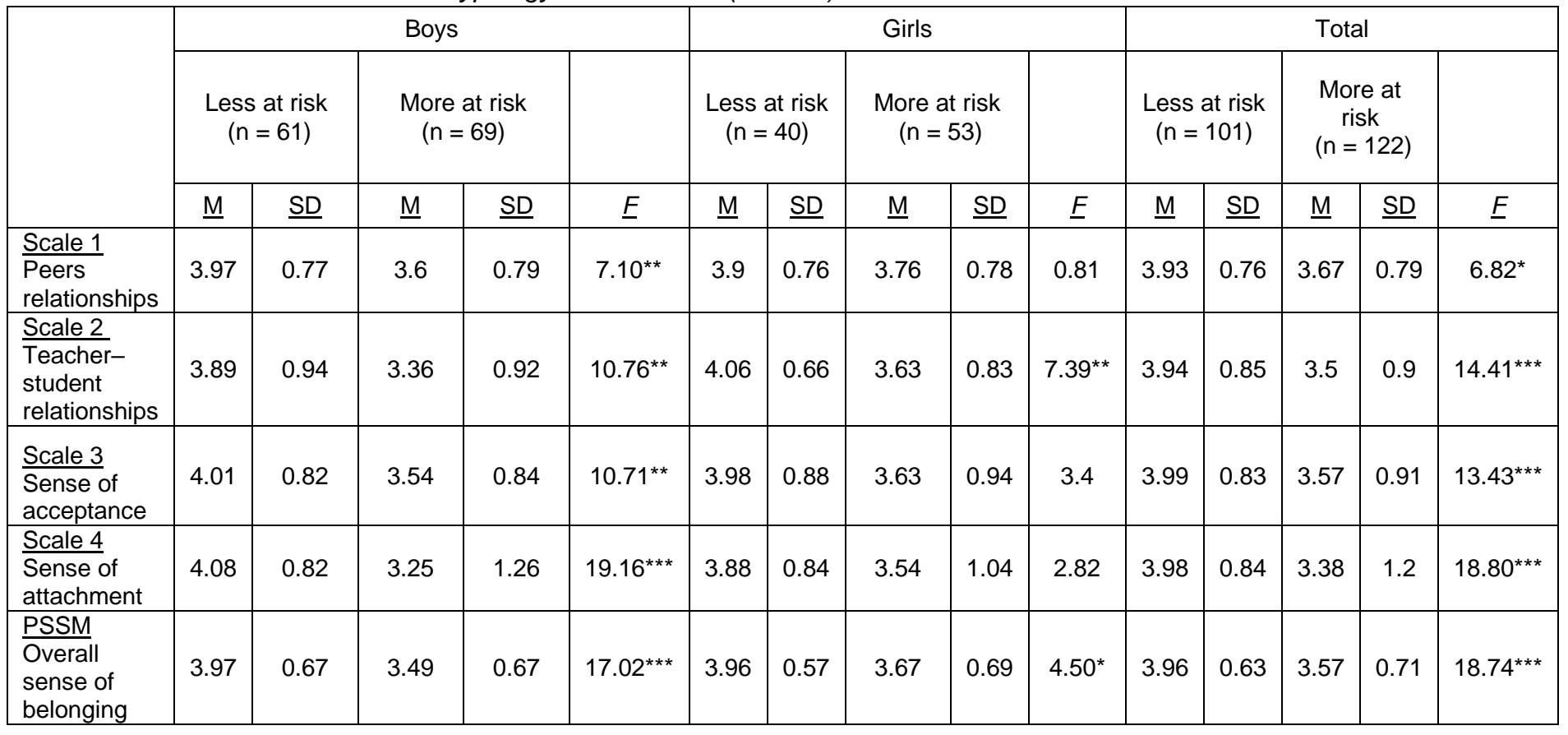

${ }^{*} p<.05$

${ }^{* *} p<.01$

${ }^{* * *} p<.001$

When using the Dropout Process measure, Table 11 shows that, for the total group, the analysis of variance provides significant results, especially for the sense of acceptance $\left(F_{(2.226)}=19.12 ; p<.001\right)$, the sense of attachment $\left(F_{(2.226)}=16.96 ; p<.001\right)$, and the overall sense of belonging $\left(F_{(2.226)}=12.51 ; p<.001\right)$, which were able to discriminate very significantly between students who were "Engaged" in a Dropout Process from those who were "Not Engaged" for the composite PSSM score. Teacher-student relationships were not significant while peers' relationships were only moderately significant $\left(F_{(2.226)}=5.66 ; p<.05\right)$. For the girls, only the sense of acceptance was significant $\left(F_{(2.91)}=8.93 ; p<.01\right)$. Our analysis for the boys group provided better results as the sense of acceptance $\left(F_{(2.133)}=\right.$ $10.16 ; p<.01)$, the sense of attachment $\left(F_{(2.133)}=14.76 ; p<.001\right)$, and the overall sense of belonging to school $\left(F_{(2.133)}=8.99 ; p<.01\right)$ were all significant.

Table 11. Analysis of Variance (ANOVA) Between the PSSM Scales and the Dropout Process Measure $(n=228)$

\begin{tabular}{|c|c|c|c|c|c|c|c|c|c|c|c|c|c|c|c|}
\hline & \multicolumn{5}{|c|}{ Boys } & \multicolumn{5}{|c|}{ Girls } & \multicolumn{5}{|c|}{ Total } \\
\hline & \multicolumn{2}{|c|}{$\begin{array}{c}\text { Not } \\
\text { engaged in } \\
\text { process ( } n \\
=103)\end{array}$} & \multicolumn{2}{|c|}{$\begin{array}{l}\text { Engaged in } \\
\text { process }(n= \\
32)\end{array}$} & \multirow[b]{2}{*}{$\underline{F}$} & \multicolumn{2}{|c|}{$\begin{array}{c}\text { Not } \\
\text { engaged in } \\
\text { process } \\
(n=67)\end{array}$} & \multicolumn{2}{|c|}{$\begin{array}{l}\text { Engaged in } \\
\text { process }(n= \\
26)\end{array}$} & \multirow[b]{2}{*}{$\underline{F}$} & \multicolumn{2}{|c|}{$\begin{array}{c}\text { Not } \\
\text { engaged in } \\
\text { process } \\
(n=170)\end{array}$} & \multicolumn{2}{|c|}{$\begin{array}{l}\text { Engaged in } \\
\text { process }(n= \\
58)\end{array}$} & \multirow[b]{2}{*}{$\underline{F}$} \\
\hline & $\underline{M}$ & $\underline{\mathrm{SD}}$ & $\underline{M}$ & $\underline{\mathrm{SD}}$ & & $\underline{M}$ & $\underline{\mathrm{SD}}$ & $\underline{M}$ & $\underline{\mathrm{SD}}$ & & $\underline{M}$ & $\underline{\mathrm{SD}}$ & $\underline{M}$ & $\underline{\mathrm{SD}}$ & \\
\hline $\begin{array}{l}\text { Scale 1 } \\
\text { Peers } \\
\text { relationships }\end{array}$ & 3.82 & 0.8 & 3.55 & 0.8 & 2.80 & 3.90 & 0.68 & 3.62 & 0.95 & 2.41 & 3.85 & 0.74 & 3.58 & 1.04 & $5.66^{*}$ \\
\hline $\begin{array}{l}\text { Scale } 3 \\
\text { Sense of } \\
\text { being } \\
\text { accepted }\end{array}$ & 3.87 & 0.8 & 3.34 & 0.90 & $10.16^{* *}$ & 3.95 & 0.84 & 3.34 & 1.01 & $8.93^{\star *}$ & 3.90 & 0.82 & 3.34 & 0.94 & $19.12^{\star \star \star}$ \\
\hline
\end{tabular}




\begin{tabular}{|c|c|c|c|c|c|c|c|c|c|c|c|c|c|c|c|}
\hline $\begin{array}{l}\text { Scale } 4 \\
\text { Sense of } \\
\text { being } \\
\text { attached }\end{array}$ & 3.81 & 1 & 2.95 & 1.4 & $14.76^{* * *}$ & 3.88 & 0.84 & 3.54 & 1.04 & 2.64 & 3.80 & 0.99 & 3.16 & 1.22 & $16.96^{\star * *}$ \\
\hline
\end{tabular}

Using only the Dropout Status measure (student is out of school at the end of the year: yes/no), we first tried to see how the PSSM and its factors, taken in February, could predict the dropping out of those students a few months later (June). As can be seen in Table 12, the global PSSM score in February was able to predict a significant number of dropouts in June of the same year $\left(F_{(2.232)}=4980 ; p<.027\right)$. Scales 3 and 4 , related to the senses of acceptance and attachment to the school, were even better performing in their capabilities to predict future dropouts $\left(F_{(2.232)}=12.471 ; p<.000\right)$ and $\left(F_{(2.232)}=9.453 ; p<.002\right)$.

Table 12. Analysis of Variance (ANOVA) Between Scores of Sense of Belonging of Students Having School Problems (February) and Their Dropout Status (June)

\begin{tabular}{|c|c|c|c|c|c|}
\hline \multirow{3}{*}{$\begin{array}{l}\text { Sense of belonging } \\
\text { (February) }\end{array}$} & \multicolumn{5}{|c|}{ Dropout Status (June) } \\
\hline & \multicolumn{2}{|c|}{ Dropout $(n=13)$} & \multicolumn{2}{|c|}{ No Dropout $(n=221)$} & \multirow[b]{2}{*}{$\underline{F}$} \\
\hline & $\underline{\mathrm{M}}$ & $\underline{\mathrm{SD}}$ & $\underline{\mathrm{M}}$ & $\underline{\mathrm{SD}}$ & \\
\hline $\begin{array}{c}\text { Scale } 1 \text { (Peers' } \\
\text { relationships) }\end{array}$ & 3.62 & 0.79 & 3.80 & 0.77 & 0.64 \\
\hline $\begin{array}{c}\text { Scale } 2 \text { (Teacher- } \\
\text { student } \\
\text { relationships) }\end{array}$ & 3.50 & 1.12 & 3.70 & 0.89 & 0.64 \\
\hline $\begin{array}{c}\text { Scale } 3 \text { (Sense of } \\
\text { acceptance) }\end{array}$ & 2.92 & 1.21 & 3.80 & 0.85 & $12.47^{\star * *}$ \\
\hline $\begin{array}{c}\text { Scale } 4 \text { (Sense of } \\
\text { attachment) }\end{array}$ & 2.77 & 1.40 & 3.70 & 1.04 & $9.45^{\star \star}$ \\
\hline $\begin{array}{l}\text { PSSM (Sense of } \\
\text { overall belonging) }\end{array}$ & 3.33 & 0.92 & 3.77 & 0.67 & $4.98^{*}$ \\
\hline
\end{tabular}

\section{Discussion}

The objective of Study 2 was to examine how the PSSM behaves in relation to at-risk students from special high schools. For the group of at-risk students, our results showed that the global PSSM score and the factors related to the sense of attachment to the school and the sense of being accepted had a significant link with the action of dropping out of school six months later. If we put our results into a continuum, we see that the PSSM and all four scales were able to discriminate between "More at risk" and "Less at risk" students for the Dropout Typology classification. When using the Dropout Process measure (which is conceptually closer to the actual dropout), only Scale 3 (sense of acceptance), Scale 4 (sense of attachment), and the PSSM (sense of overall belonging) correctly discriminated students who were "Engaged" or "Not Engaged" in a Dropout Process. Finally, when using the actual Dropout Status measure, results were the same, i.e., Scales 3, 4, and the composite PSSM score were the only ones that could predict the actual dropping out of school of those students from disadvantaged schools.

Thus, a main finding of our study with the PSSM is that, when it comes to identifying what school factors were related to students dropping out of school, and even though we found that the quality of relationships in school was indeed very important, scales that were linked to the sense of acceptance (Scale 3) and the sense of attachment (Scale 4) far outweighed those linked to the quality of relationships between students and their peers/teachers (Scales 1 and 2). That is, scales related to personal school experience were more important than 
scales related to the social aspect of going to school. This finding supports the views of researchers who believe that general interest in school and ultimately, dropping out of school, are more than a simple question of social relation abilities (Archambault et al., 2016; Battin-Pearson, Newcomb, Abbott, Hill, Catalano, \& Hawkins, 2000; Jimerson, Egeland, Sroufe, \& Carlson, 2000; Smith, Moreau, Paquin, St-Amand, \& Chouinard, in press).

Our results indicated that dropout was predicted more strongly by the sense of attachment and the sense of acceptance. First, the sense of attachment echoes students' positive feelings about the school environment. Researchers suggest many emotions that can describe the feeling of belonging; some suggest maintaining "emotional ties" (Mucchielli, 1980), feeling intimacy (Kestenberg and Kestenberg, 1988), feeling useful and united (Mucchielli, 1980), feeling proud (Janosz et al., 1998) or to feel good (Mucchielli, 1972). On a theoretical level, positive emotions play a significant role in the relationship made up of the feeling of belonging and school engagement. Anderman and Freeman (2004) developed a theoretical model based on the work of Baumeister and Leary (1995) which examines several aspects of the processes that make up the complex relationship between belonging and school engagement. These authors explain that belonging can directly influence school engagement. In turn, school engagement directly influences academic achievement. In these psychological processes, positive emotions partially and positively mediate the relationship between the feeling of belonging and school engagement (St-Amand, Bowen, Bulut, Cormier, Janosz, \& Girard, in press). Second, the sense of acceptance mirrors the student's perception toward the treatment he or she receives from the school environment. From a theoretical perspective, Juvonen (2006) suggests that the sense of acceptance is associated with academic achievement. This researcher also emphasizes that the sense of acceptance among peers contribute to students' sense of belonging. Stressing the importance to be accepted by the members of the school community to succeed in school, Wehlage et al. (1989) suggested that teachers should offer: (1) support for students with difficulties; (2) support for students so that they develop skills required by the school; (3) support so that students feel included; (4) support so that students build and maintain respectful relationships.

All these results support the PSSM as being a reliable tool to measure the sense of belonging of students toward their schools. The PSSM can also be used as a tool to help identify students who are at risk of dropping out of school. However, caution is required when using the PSSM for this purpose as its capacity to predict behaviors fluctuates considerably depending on the type of students and conduct. A final note about possible differences between scores from boys and girls in this study: during all the analyses we made, we found that the PSSM scores for girls were higher than those of boys. The difference was sometimes very small and sometimes much larger but no matter the time of the year the data were analyzed, girls consistently reported higher PSSM scores than boys. This was true for the composite score of belonging (PSSM) and also for each of the four scales related to the PSSM. Finally, we must caution again from the use of the PSSM as an absolute tool for predicting future outcomes or behaviors from students. It is an instrument that can certainly help identify and track at-risk students but observations should be backed by other means of control, which could complement the PSSM in this use.

\section{Together result and discussion}

Together, the results of these analyses indicate the multidimensional nature of the PSSM and the partial invariance of the Psychological Sense of School Membership (PSSM) regarding the gender of the participants. Among the many reasons as to why the PSSM is partially invariant, Brown (2006) suggests: (1) the inadequate translation of the items; (2) the different interpretations of the items; or (3) the presence of cultural bias on the part of the participants. Besides, rarely do we find in research the validation of an instrument using that methodological perspective. Gregorich (2006) explained: "Why is factorial invariance testing relatively rare? One possibility is that many investigators lack the requisite technical skills [...]. Perhaps a more fundamental possibility is a lack of awareness in the scientific community [...]" (p. 2). The results also illustrate that belonging (the sense of acceptance and the sense of attachment) plays a pivotal role in predicting students' dropout. Thus, it would be beneficial for teachers to consult some of the available works that provide a better understanding of the potential effect of effective strategies on students' dimensions of 
belonging such as the sense of acceptance and the sense of attachment (Osterman, 2010; Smith, Moreau, Paquin, St-Amand, \& Chouinard, in press; St-Amand, Girard, \& Smith, 2017). Indeed, Osterman (2010) describes some studies aimed at identifying various attitudes/behaviors of teachers that may positively influence these two dimensions of belonging. Osterman proposes two roles that teachers should adopt. These roles if adopted properly may generate positive emotions (the sense of attachment) and acceptance: (1) a role of academic support (teacher as pedagogical leader); and (2) an interpersonal support role (teacher as a person). Among these educational strategies, Osterman (2010) suggested giving examples, checking for students' understanding, engaging in problem solving, and giving choices to students (teacher as pedagogical leader). Second, Osterman (2010) used an expression, "teacher as a person", to emphasize that teaching strategies alone are not enough to develop students' sense of belonging to school. In everyday life, teachers must demonstrate adequate interpersonal support as students perceive a good teacher through caring and acceptance behaviors; this can also include giving students tips, knowing students' names, listening to their concerns, using humor, etc. (Osterman, 2010). We believe these strategies can generate student's positive emotions (the sense of attachment) toward school and enhance their sense of acceptance.

\section{References}

Abubakar, A., van de Vijver, F. J. R., Alonso-Arbiol, I., Suryani, A. O., Pandia, W. S., Handani, P., ... \& Murugumi, M. (2016). Assessing sense of school belonging across cultural contexts using the PSSM: Measurement and functional invariance. Journal of Psychoeducational Assessment, 34(4), 380-388. doi: 10.1177/0734282915607161

Allen, K., Kern, M. L., Vella-Brodrick, D., Hattie, J., \& Waters, L. (2016). What schools need to know about fostering school belonging: A meta-analysis. Educational Psychology Review, 30(1), 1-34. doi: 10.1007/s10648-016-9389-8

Almås, I., Cappelen, A. W., Salvanes, K. G., Sørensen, E. Ø., \& Tungodden, B. (2016). What explains the gender gap in college track dropout? Experimental and administrative evidence. American Economic Review, 106(5), 296-302. doi: 10.1257/aer.p20161075

Anderman, L. H., \& Freeman, T. M. (2004). Students' sense of belonging in school. Dans P. R. Pintrich \& M. L. Maehr (dir.), Motivating students, improving schools: The legacy of Carol Midgley (vol. 13, pp. 27-63). Oxford, England: Elsevier.

Archambault, I., Janosz, M., Dupéré, V., Brault, M.-C., \& Mc Andrew, M. (2017). Individual, social, and family factors associated with high school dropout among low.SES youth: Differential effects as a function of immigrant status. British Journal of Educational Psychology, 87(3), 456477. doi: 10.1111/bjep.12159

Battin-Pearson, S., Newcomb, M. D., Abbott, R. D., Hill, K. G., Catalano, R. F., \& Hawkins, J. D. (2000). Predictors of early high school dropout: A test of five theories. Journal of Educational Psychology, 92(3), 568-582. doi: 10.1037/0022-0663.92.3.568

Baumeister, R. F., \& Leary, M. R. (1995). The need to belong: Desire for interpersonal attachments as a fundamental human motivation. Psychological Bulletin, 117(3), 497- 529. doi: 10.1037/0033-2909.117.3.497

Belfield, R. C., \& Levin, H. M. (2005, october). The social costs on inadequate education. In H. Levin (Chair), Teachers College symposium on educational equity [symposium]. Conference conducted at Teachers College, New York, NY.

Berktold, J., Geis, S., \& Kaufman, P. (1998). Subsequent educational attainment of high school dropouts. Postsecondary education descriptive analysis reports (Publication No. NCES-98- 085). Washington, DC: U.S. Department of Education.

Boily, R. (2002). Étude descriptive longitudinale du sentiment d'appartenance envers l'école chez des élèves du secondaire des secteurs publics et privés. (unpublished manuscript). Université de Montréal, Montréal, QC.

Brooks-Gunn, J., \& Duncan, G. J. (1997). The effects of poverty on children. The Future of Children, 7(2), 55-71. doi: 10.2307/1602387 
Brown, T. A. (2006). Confirmatory factor analysis for applied research. New York, NY: Guilford Press.

Brown, T. A. (2015). Confirmatory factor analysis for applied research (2 ${ }^{\text {nd }}-$ ed.). New York, NY: Guilford Press.

Browne, M., \& Cudeck, R. (1993). Alternative ways of assessing model fit. In K. A. Bollen \& J. S. Long (Eds.), Testing structural equation models (pp. 136-162). Newbury Park, CA: Sage.

Byrne, B. M. (2004). Testing for multigroup invariance using AMOS graphics: A road less traveled. Structural Equation Modeling: A multidisciplinary Journal, 11(2), 272-300.

Byrne, B. M. (2008). Testing for multigroup equivalence of a measuring instrument: A walk through the process. Psicothema, 20(4), 872-882.

Byrne, B. M. (2016). Structural equation modeling with AMOS: Basic concepts, applications, and programming (3rd ed.). New York, NY: Routledge.

Cheung, H. Y. (2004). Comparing Shanghai and Hong Kong students' psychological sense of school membership. Asia Pacific Education Review, 5(1), 34-38. doi: 10.1007/BF03026277

Cheung, H. Y., \& Hui, S. K. F. (2003). Mainland immigrant and Hong Kong local students' psychological sense of school membership. Asia Pacific Education Review, 4(1), 67- 74. doi: 10.1007/BF03025553

Christenson, S. L., \& Thurlow, M. L. (2004). School dropouts: Prevention considerations, interventions, and challenges. Current Directions in Psychological Science, 13(1), 36- 39. doi: 10.1111/j.0963-7214.2004.01301010.x

Deci, E. L., \& Ryan, R. M. (2000). The "What" and "Why" of goal pursuits: Human needs and the self-determination of behavior. Psychological Inquiry, 11(4), 227-268. doi:

0.1207/S15327965PLI1104_01

Eccles, J. S., \& Roeser, R. W. (2009). Schools, academic motivation, and stage- environment fit. In R. M. Lerner \& L. Steinberg (Eds.), Handbook of adolescent psychology (3rd ed., pp. 404434). Hoboken, NJ: Wiley.

Finn, J. D. (1989). Withdrawing from school. Review of Educational Research, 59(2), 117- 142. doi: $10.3102 / 00346543059002117$

Flynn, T. M. (1997). A sense of school membership and extracurricular activities (Unpublished doctoral dissertation). University of Pittsburgh, PA.

Freeman, J., \& Simonsen, B. (2015). Examining the impact of policy and practice interventions on high school dropout and school completion rates: A systematic review of the literature. Review of Educational Research, 85(2), 205-248. doi: 10.3102/0034654314554431

Gaete, J., Montero-Marin, J., Rojas-Barahona, C. A., Olivares, E., \& Araya, R. (2016). Validation of the Spanish version of the Psychological Sense of School Membership (PSSM) Scale in Chilean adolescents and its association with school-related outcomes and substance use. Frontiers in Psychology, 7, 1901. doi: 10.3389/fpsyg.2016.01901

Gillen-O'Neel, C., \& Fuligni, A. (2013). A longitudinal study of school belonging and academic motivation across high school. Child Development, 84(2), 678-692. doi: 10.1111/j.14678624.2012.01862.x

Goodenow, C. (1993a). The psychological sense of school membership among adolescents: Scale development and educational correlates. Psychology in the Schools, 30(1), 79-90. doi: 10.1002/1520-6807(199301)30:1<79::AID PITS2310300113>3.0.CO;2-X

Goodenow, C. (1993b). Classroom belonging among early adolescent students: Relationships to motivation and achievement. Journal of Early Adolescence, 13(1), 21-43. doi:

$10.1177 / 0272431693013001002$

Goodenow, C., \& Grady, K. E. (1993). The relationship of school belonging and friends' values to academic motivation among urban adolescent students. The Journal of Experimental Education, 62(1), 60-71. doi: 10.1080/00220973.1993.9943831

Hagborg, W. J. (1994). An exploration of school membership among middle- and high- school 
students. Journal of Psychoeducational Assessment, 12(4), 312-323. doi:

$10.1177 / 073428299401200401$

Hagborg, W. J. (1998). An investigation of a brief measure of school membership.

Adolescence, 33(130), 461-468.

Hagerty, B. M., Williams, R. A., Coyne, J. C., \& Early, M. R. (1996). Sense of belonging and indicators of social and psychological functioning. Archives of Psychiatric Nursing, 10(4), 235-244. doi: 10.1016/S0883-9417(96)80029-X

Hagerty, B. M.K., Lynch-Sauer, J., Patusky, K. L., Bouwsema, M., \& Collier, P. (1992). Sense of belonging: A vital mental health concept. Archives of Psychiatric Nursing, 6(3), 172-177. doi: 10.1016/0883-9417(92)90028-H

Hu, L.-T., \& Bentler, P. M. (1999). Cutoff criteria for fit indexes in covariance structure analysis: Conventional criteria versus new alternatives. Structural Equation Modeling: A Multidisciplinary Journal, 6(1), 1-55. doi: 10.1080/10705519909540118

Janosz, M., Deniger, M-A., Roy, G., Lacroix, M., Fallu, J-S., Langevin, L., \& Le Blanc,

M. (2001). Évaluation de programmes de prévention du décrochage scolaire pour adolescents de milieux défavorisés 1998-2000 (Publication No. 98-DS-001). Montreal, QC: Centre de Recherche et d'Intervention sur la Réussite Scolaire (CRIRES) et Institut de Recherche pour le Développement Social des Jeunes (IRDS).

Janosz, M., Georges, P., \& Parent, P. (1998). L'environnement socioéducatif à l'école secondaire : un modèle théorique pour guider l'évaluation du milieu. Revue Canadienne de Psychoéducation, 27(2), 285-306.

Janosz, M., Le Blanc, M., Boulerice, B., \& Tremblay, R. E. (2000). Predicting different types of school dropouts: A typological approach on two longitudinal samples. Journal of Educational Psychology, 92(1), 171-190. doi: 10.1037/0022-0663.92.1.171

Jimerson, S., Egeland, B., Sroufe, L.A., \& Carlson, B. (2000). A prospective longitudinal study of high school dropouts: Examining multiple predictors across development. Journal of School Psychology, 38(6), 525-549. doi: 10.1016/S0022-4405(00)00051-0

Juvonen, J. (2006). Sense of belonging, social bonds, and school functioning. In P. A. Alexander \& P. H. Winne (Eds.), Handbook of educational psychology (2nd ed., pp. 655-674). Mahwah, NJ: Erlbaum.

Kestenberg, M., \& Kestenberg, J. S. (1988). The sense of belonging and altruism in children who survived the Holocaust. Psychoanalytic Review, 75(4), 533-560.

Kline, R. B. (2011). Principles and practice of structural equation modeling (3rd ed.). New York, NY: Guilford Press.

Lavigne, G. L., Vallerand, R. J., \& Crevier-Braud, L. (2011). The fundamental need to belong: On the distinction between growth and deficit-reduction orientations. Personality and Social Psychology Bulletin, 37(9), 1185-1201. doi: 10.1177/0146167211405995

Le Blanc, M., McDuff, P., \& Fréchette, M. (1998). MASPAQ, Manuel sur des mesures de l'adaptation scolaire et personnelle pour les adolescents québécois. Montreal, QC: École de psychoéducation de l'Université de Montréal.

McCuish, E. C., Lussier, P., \& Corrado, R. R. (2015). Examining antisocial behavioral antecedents of juvenile sexual offenders and juvenile non-sexual offenders. Sexual Abuse, 27(4), 414-438. doi: 10.1177/1079063213517268

Moretti, E. (2007). Crime and costs of criminal justice. In C. R. Belfield \& H. M. Levin (Eds.), The price we pay: Economic and social consequences of inadequate education (pp. 142-159). Washington, DC: Brookings Institution Press.

Mucchielli, R. (1972). Options et changement d'opinion. Paris, France: ESF.

Mucchielli, R. (1980). Le travail en groupe. Paris, France: ESF.

Muennig, P. (2007). Consequences in health status and costs. In C. R. Belfield \& H. M. Levin 
(Eds.), The price we pay: Economic and social consequences of inadequate education (pp. 125141). Washington DC: Brookings Institution Press.

O'Farrell, S. L., \& Morrison, G. M. (2003). A factor analysis exploring school bonding and related constructs among upper elementary students. The California School Psychologist, 8(1), 53-72. doi: 10.1007/BF03340896

Osterman, K. F. (2000). Students' need for belonging in the school community. Review of Educational Research, 70(3), 323-367. doi: 10.3102/00346543070003323

Osterman, K. F. (2010). Teacher practice and students' sense of belonging. In T. Lovat, R. Toomey, \& N. Clement (Eds.), International research handbook on values education and student wellbeing (pp. 239-260). Dordrecht, The Netherlands: Springer.

Pekrun, R., Elliot, A. J., \& Maier, M. A. (2006). Achievement goals and discrete achievement emotions: A theoretical model and prospective test. Journal of educational Psychology, 98(3), 583-597. doi: 10.1037/0022-0663.98.3.583

Roeser, R. W., Midgley, C., \& Urdan, T. C. (1996). Perceptions of the school psychological environment and early adolescents' psychological and behavioral functioning in school: The mediating role of goals and belonging. Journal of Educational Psychology, 88(3), 408-422. doi: 10.1037/0022-0663.88.3.408

Rouse, C. E. (2007). Consequences for the labor market. In C. R. Belfield \& H. M. Levin (Eds.), The price we pay: Economic and social consequences of inadequate education (pp. 99-124). Washington, DC: Brookings Institution Press.

Rumberger, R. W. (2011). Dropping out: Why students drop out of high school and what can be done about it. Cambridge, MA: Harvard University Press.

Smith, J., Moreau, D., Paquin, S., St-Amand, J., \& Chouinard, R. (in press). The evolution of motivation to learn in the context of the transition to secondary school: Developmental trajectories and relational determinants. The International Journal of Pedagogy and Curriculum.

St-Amand, J., Bowen, F., Dulut, O., Cormier, D., Janosz, M. \& Girard, S. (in press). Le sentiment d'appartenance à l'école : validation d'un modèle théorique prédisant l'engagement et le rendement scolaire en mathématiques. Formation et Profession.

St-Amand, J., Bowen, F., \& Lin, T. W. J. (2017). Le sentiment d'appartenance à l'école: une analyse conceptuelle. Canadian Journal of Education / Revue canadienne de l'éducation, 40(1), $1-32$.

St-Amand, J., Girard, S., \& Smith, J. (2017). Sense of belonging at school: Defining attributes, determinants, and sustaining strategies. IAFOR Journal of Education, 5(2), 105-119. doi: 10.22492/ije.5.2.05

Stearns, E., \& Glennie, E. J. (2006). When and why dropouts leave high school. Youth \& Society, 38(1), 29-57. doi: 10.1177/0044118X05282764

Tabachnick, B. G., \& Fidell, L. S. (2013). Using multivariate statistics (6 $6^{\text {th }}$ edition).

Boston, MA: Pearson.

Togari, T., Sato, M., Yamazaki, Y., \& Otemori, R. (2011). The development of Japanese 13-item version of psychological sense of school membership scale for Japanese urban high school students. Health, 7, 62-72. doi: 10.20812/jash.SH-2011_049

Vera, E. M., Polanin, J. R., Polanin, M., \& Carr, A. L. (2018). Keeping Latina/o students in school: Factors related to academic intentions of students at risk for school dropout. Journal of Latina/o Psychology, 6(1), 34-48. doi: 10.1037/lat0000082

Wagle, R., Dowdy, E., Yang, C., Palikara, O., Castro, S., Nylund-Gibson, K., \& Furlong,

M. J. (2018). Preliminary investigation of the psychological sense of school membership scale with primary school students in a cross-cultural context. School Psychology International, 39(6), 568-586. doi: 10.1177/0143034318803670

Waldfogel, J., Garfinkel, I., \& Kelly, B. (2007). Welfare and the costs of public assistance. In C. R. Belfield \& H. M. Levin (Eds.), The Price we pay: Economic and social consequences of 
inadequate education (pp. 160-174). Washington, DC: Brookings Institution Press.

Walker, L. O., \& Avant, K. C. (2011). Strategies for theory construction in nursing (5th ed.). Boston, MA: Prentice Hall.

Wehlage, G. G., Rutter, R. A., Smith, G. A., Lesko, N., \& Fernandez, R. R. (1989). Reducing the risk: Schools as communities of support.

Philadelphia, PA: Falmer Press. Ye, F., \& Wallace, T. L. (2014). Psychological sense of school membership scale: Method effects associated with negatively worded items. Journal of Psychoeducational Assessment, 32(3), 202-215. doi: 10.1177/0734282913504816

You, S., Ritchey, K. M., Furlong, M. J., Shochet, I., \& Boman, P. (2011). Examination of the latent structure of the Psychological Sense of School Membership Scale. Journal of Psychoeducational Assessment, 29(3), 225-237. doi: 10.1177/0734282910379968 